\title{
THE ROLE AND INFLUENCE OF ACCOUNTING SYSTEM AND EFFECTIVE CONTROL THROUGH ACCOUNTING PROCEDURES AND METHODS IN COMBATING AND REDUCING TAX EVASION
}

\author{
Dr. Badir Mohammed Alwan \\ Assistant Professor, Faculty of Administrative and Financial Science \\ Department of Accounting
}

Doi: 10.19044/elp.v1 no2a6 URL:http://dx.doi.org/10.19044/elp.v1no2a6

\begin{abstract}
The purpose of this study is to identify the Information System used at Income and Sales Tax Department, and the impact it has on the effectiveness of income tax in the State throughout the development of computers and software used in the department, as well as the role of the impact public and private departments in providing useful quantitative and qualitative information.

Set of assumptions have been formed by the researcher to achieve the purposes of the study and to answer its questions. Furthermore, the results of the study show that the increase of the effectiveness of sales and income tax department is impacted by all the independent variables subject matter of this study. The most influencing variable is the used computers and software contributions in information systems; followed by the development of the information systems at sales and income tax department, the final influencing variable is the activation of governmental organizations and directorates role by providing the accurate information for the department. Moreover, statistic analysis revealed a profound association between tax evasion and accounting system through the penal and control system
\end{abstract}

Keywords: Accounting systems, combating tax evasion

\section{Chapter I: Study Framework Introduction}

The concept of accounting has improved from bookkeeping to an information system. The American Accounting Association AAA has defined accounting as "the process of identifying, measuring and 
communicating economic information to permit informed judgments and decisions by users of the information!"

The accounting as an information system serves to collect and communicate the economic information related to economic activities of the business or organization to a wide range of users. Sales and income tax department is one of the leading governmental institutions and departments to depend on the reports of the information systems issued by taxed companies and economical units. The outputs of these systems form a foundation to assess companies and individuals, as well as the clients and suppliers of such companies and units; resulting in the increase of the number of tax payers and increase the objectivity of the assessors' judgments. Consequently, this will lead to reducing tax evasion and increasing tax department's collection and effectiveness, in addition to achieving the economic, financial and social purposes.

\section{First: the subject of Study}

Currently, taxes are the most important recourses of the state. Statements of the Ministry of Finance indicate that taxes are the main resource of revenue for State's Treasury in Jordan. This case is not restricted to Jordan only; it applied to all other countries worldwide. Accordingly, the importance of studying taxes and their problems came to existence.

Tax evasion is a serious problem affecting many states; and the main reasons for this problem are:-

- Insufficiencies and Deficiencies in the accounting and controlling system.

- Lack of effective controlling system under intuitive information technology.

- Non compliance and non applicability of tax laws.

\section{Second: The Importance of Study}

The significant development of modern technology especially of computers and communication in addition to the movement from Management Era to the Information Era increased the importance of information system development to keep abreast with these developments and to provide qualified manpower, materials possibilities and activation of the used computers and software.

This study examined The role of the importance of information system development used at sales and income tax department to achieve the department's purposes to broaden the base of taxpayers, to increase tax collection through the statements of all income sources and reducing the attempts of tax reduction and combating tax evasion which serves assessors in making more accurate and objective decisions. Consequently, it works on 
Confidence-building between the department from one side and taxpayers on the other hand.

\section{Hypotheses of the Study}

Some Hypotheses have been achieved through this study:-

- No association between accounting system and tax evasion with statistically significance at the level $\geq 5 \%$.

- No association between experience and tax evasion with statistically significance at the level $\geq 5 \%$.

- Tax evasion is not varying with tax price with statistically significance at the level $\geq 5 \%$.

- No association between penal system and tax evasion with statistically significance at the level $\geq 5 \%$.

\section{Objectives of Study}

This study aims to achieve the following purposes.

- Identifying the compliance of accounting system with tax evasion.

- Identifying the reasons of tax evasion.

- Identifying the factors of reducing tax evasion.

- Attainment to results, recommendations and proposals to reduce tax evasion.

\section{Previous Studies}

\section{A- Arabic Studies}

1- Alessa (2000)

The role of information system in management decision making at Ministry of Education.

1- This study aimed to search about the role of information system in management decision making at the Ministry of Education in Jordan in order to recognize the role of information system in decision making at the Ministry, to identify the comprehensiveness of the information system and to identify the role of information system in management decision making at the Ministry of Education. Adel Musa Mohammad Alessa - unpublished Master Thesis - Arab Academy for Banking and Financial Sciences Amman 1999/2000.

\section{Mohammad Islam Qasem Abdul Kareem} direct tax)

(January- $1^{\text {st }} .2011$ - Tax Accounting System role in the assessment of

This study examined the role and influence of the Tax Accounting System in the assessment of direct tax upon the revenue of the Sudan. The 
importance of this study is in highlighting the tax accounting system through a scientific perspective and the role of direct tax in development. The subject of the research is the lack of coordination between tax income departments and the commitment of applying the accounting system assessment the direct tax proceeds hence the lack of contributions in a state's public revenue. The research's hypotheses in efficient accounting system leads to sound tax assessment meanwhile, a lack of tax proceeds in general, direct tax proceeds in particular, lack of coordination between tax proceeds departments and tax credits reduced tax with outbreak of tax evasion. This study aims to identify the role of the accounting system in direct tax assessment, to identify accounting system commitment in tax assessment and to identify the direct tax with clarifying its impacts and types upon revenues. The researcher found outcomes as lack of tax proceeds in general, direct tax in particular in addition to tax evasion and loss of confidence between financer and Taxation Chamber, shorten of tax umbrella, weakness of information system and lack of human cadre. The recommendations are the following: potentials development in all respects of Taxation Chamber in achieving tax fairness, combating tax evasion and build the bridges of confidence between financer and Taxation Chamber.

\section{Abu Alfuttuh Study 2011}

The study refers to the challenges that may face banking sector in Egypt because of American Tax Law issued in 2010 which is applied in 2013, whereas the study highlighted the increase in operating costs and radical changes in payments systems and clients' data beard by banking institutions as a result for applying Foreign Account Tax Compliance Act (FACTA). The study introduced set of solutions for some challenges faced banks when this law is applied.

\section{Foreign Studies}

\section{First Study: Mars an \& Dean: 2010}

The study mentioned the necessity of global financial system to execute FACTA's demands, to prepare financial reports and to deduct tax at source for all Americans external accounting transactions in order to reduce tax evasion for United States and countries signed in agreement to carry on the obligation of this law, to achieve tax savings at governmental level and to be suggested in commitment it and all countries must be associated by agreements to execute this law to gain dual benefits and reciprocity.

\section{Second Study: Fariz Huseynov 2012.}

This study examines the relation between tax avoidance and tax management corporate social responsibilities by applying FATCA's law, the 
ways of operating costs development and possible losses resulted by the avoidance. Consequently, it firms to get rid of bad methods of tax avoidance because it reflects the negative side in contributing the legal persons share in public expenditure and tax management must be participated in introducing full discloser of peoples' tax to execute the perfect commitment of FATCA's law demands in full discloser and to ensure all Americans' transactions outside the United States with full commitment of paying taxes voluntarily because they carry the American nationality, subsequently, to avoid penalties and fines.

\section{Third Study: Christopher 2012}

This study examines the savings achieved by institutions as tax planning to avoid commitment risks of applying FATCA's law and to avoid the non-disclosure fines of external corporations transactions or nondisclosure of financial assets outside the United States as well as dealing with transferring price in order to avoid the high tax rate at residential country as the study refers to the importance of corporation tax planning to maintain tax savings when it depends on one of tax advisor who avoids the compliance of high tax rate or at least to avoid fines. Meanwhile, the study recommended the global banks to make procedures of costs budgets and benefits before starting the applying FATCA's law.

\section{I.}

\section{Theoretical Framework Tax Evasion}

Financer works to be digressed from tax, get rid of it or transfer it to another person because it makes an additional burden for him. Digressive tax means that taxpayers could avoid paying taxes legally without transferring it to another person, whereas transferring it to another person is moving the tax burden to another person after being fulfilled, which means the stability of tax burden, incidence of a tax or tax incidence.

\section{Meaning of Tax Evasion}

It is the way used by financer trying to non-paying all or some accrued taxes through one of used methods in order to avoid taxpaying by using different and many ways of deceptions, so Tax Fraud is a synonym to Tax Evasion, which might be through tax assessment and when financer tries to obscure some taxable materials or when financer obscure his funds to prevent the financial management from collecting its rights. 


\section{Differences between Tax Evasion \& Tax Avoidance}

Some writers found tax avoidance and tax evasion are the same, some of them considered tax avoidance is a comprehensive term which refers to all types of tax evasion and tax evasion is one of its forms e.g. each of Duverger, Tardier and Rosier considered tax avoidance is an acceptable concept whereas tax evasion is not acceptable concept. On the other side other authors such as Lerouge, Piatier and Margarites depend on opposite point of view, tax avoidance is a specific concept for tax evasion which means the same source.

While some authors differentiate between tax evasion \& avoidance and agreed that tax evasion is violating the provisions of tax laws in other expression tax evasion is illegal.

Assistant Factors of Tax Evasion

First: Disadvantages in revenue law which include:

Tax Revenues are complicated.

Multiplicity of tax is being various or manifold.

Procedures of organizing tax.

Economical circumstances.

Second: Financial Management Disadvantages include:

Difficulties in tax assessment.

Inequality in applying.

Penalties: when financial management neglects in applying penalties regulated by law that leads to continued and enhanced tax evasion along with fraud.

Third: psychological factors for financers when tax evasion:

Popularity of tax consciousness.

Directing the Expenditure of State; if the state disburses the collected tax correctly in way that individuals could feel it, their tax evasion will be reduced whereas if the collected tax is spent in an un-profitable way, taxpayers will find tax evasion is excused.

\section{International Tax Evasion}

International tax evasion in general is one of the tax evasion's forms, but it takes place abroad and here taxpayer works with regional tax principle which means the states' rights in imposing taxes on accessing and activities inside regional state, but with the extending of global environment inactive this principle. Hence, the taxpayer tries to reduce tax burden with legal or illegal ways 2 - by moving commodities or his residency place to a foreign region to have the ability of tax evasion, in this case 3- he takes advantage of either fall in tax rate in comparison with his original country or from tax reliefs and concessions that he gained from hosting country particularly, countries are called Tax Haven which provide appropriate climate for 
taxpayer in order to evade from taxes that could be within legal framework according to bilateral and multilateral agreements. Tax evader depends on loopholes in legal systems not in breaking rules. 4- Hence, international tax evasion could be differentiated from internal tax evasion. Along with our trying to identify internal tax evasion, tax fraud is identified by Lucien Mehl as "breach of the levy law to evade taxes and reduce basis of tax".

\section{Accounting Systems \& Accounting Standards}

Accounting standards (rules): Those include laws and legislations which control preparing financial statements. The process of setting standards is an organizing framework or the process of forming accounting standards may be practiced in a country in different way of other country (take cognition that principles are stabled in general) so the practical applying may deviate from enforced accounting standards. The researchers mention in accounting that four reasons are existed to clarify this difference:

Lack of related penalties of non-applying accounting standard in proper way or it is not active in other countries.

Some economical units including optional for introducing nonrequired information.

In some cases the economical units are allowed by their countries to be deviated from accounting standards if that leading to proper results and represent its financial center ideally.

Applying accounting standards to the independent financial statements of institutions not for consolidated financial statements in some countries hence the countries choose other basis for accounting beside national standards when preparing consolidating statements.

\section{Hypotheses Test \\ First Hypothesis}

Through Statistic Analysis it is found that scientific hypothesis has been rejected because it represents $(0.00 \%$ less than $5 \%)$

The hypothesis was formed as the following

- There is no correlation between Accounting System and Tax Evasion at a $5 \%$ level of significance

- This hypothesis has been rejected and this indicates that there is a correlation between the Accounting System and Tax Evasion.

Next figure explains that.

Test Type: One sample test 
One-Sample Statistics

\begin{tabular}{|l|l|l|l|l|}
\hline & N & Mean & Std. Deviation & Std. Error Mean \\
\hline f1 & 44 & 1.8045 & .52560 & .07924 \\
\hline & & & & \\
\hline
\end{tabular}

One-Sample Test

\begin{tabular}{|l|l|l|l|l|l|l|}
\hline \multicolumn{2}{|l|}{ Test Value $=2.5$} \\
\cline { 5 - 7 } & T & Df & Sig. (2-tailed) & $\begin{array}{l}\text { Mean } \\
\text { Difference }\end{array}$ & \multicolumn{2}{l|}{$\begin{array}{l}\text { 95\% Confidence Interval } \\
\text { of the Difference }\end{array}$} \\
\cline { 5 - 7 } & & & & Lower & Upper \\
\hline f1 & $-8.777-$ & 43 & .000 & $-.69545-$ & $-.8553-$ & $-.5357-$ \\
\hline
\end{tabular}

\section{Second Hypothesis}

Through static analysis it is found that scientific hypothesis was refused because it represents $(0.00 \%$ less than $5 \%)$

The next hypothesis is formed as the following:

There is no correlation between Experience and Tax Evasion at a 5\% level of significance.

The hypothesis has been rejected and this indicates that there is a clear correlation between Experience and Tax Evasions.

The following figure explains that:

Test Type: One sample test

One-Sample Statistics

\begin{tabular}{|l|l|l|l|l|}
\hline & N & Mean & Std. Deviation & Std. Error Mean \\
\hline $\mathrm{f} 2$ & 44 & 1.7159 & .42314 & .06379 \\
\hline
\end{tabular}

One-Sample Test

\begin{tabular}{|l|l|l|l|l|l|l|}
\hline & \multicolumn{2}{|l|}{ Test Value $=2.5$} & \multicolumn{2}{l|}{} \\
\cline { 5 - 7 } & \multirow{2}{*}{ T } & Df & Sig. (2-tailed) & $\begin{array}{l}\text { Mean } \\
\text { Difference }\end{array}$ & \multicolumn{2}{l|}{$\begin{array}{l}\text { 95\% Confidence Interval of } \\
\text { the Difference }\end{array}$} \\
\cline { 5 - 7 } & & & Lower & Upper \\
\hline f2 & $-12.292-$ & 43 & .000 & $-.78409-$ & $-.9127-$ & $-.6554-$ \\
\hline
\end{tabular}

\section{Third Hypothesis}

It was found through statistic analysis that scientific hypothesis because it represents $(0.00 \%$ less than $5 \%)$

- Tax Evasion is not affected by tax price at a 5\% level of significance

- The hypothesis has been rejected which means there is a clear effect between Tax Evasion and Tax Price. 
The following figure explains that.

Test Type: One sample Test

One-Sample Statistics

\begin{tabular}{|l|l|l|l|l|}
\hline & N & Mean & Std. Deviation & Std. Error Mean \\
\hline f3 & 44 & 2.1667 & .46311 & .06982 \\
\hline
\end{tabular}

One-Sample Test

\begin{tabular}{|l|l|l|l|l|l|l|}
\hline & \multicolumn{2}{|l|}{ Test Value $=2.5$} & & \multicolumn{2}{l|}{} \\
\cline { 5 - 7 } & & T & Df & Sig. (2-tailed) & $\begin{array}{l}\text { Mean } \\
\text { Difference }\end{array}$ & \multicolumn{2}{l|}{$\begin{array}{l}\text { 95\% Confidence Interval of } \\
\text { the Difference }\end{array}$} \\
\cline { 6 - 7 } & & & Lower & Upper \\
\hline f3 & $-4.774-$ & 43 & .000 & $-.33333-$ & $-.4741-$ & $-.1925-$ \\
\hline
\end{tabular}

\section{Fourth Hypothesis}

Through static analysis it is found that the scientific hypothesis was refused because it represents $(0.00 \%$ less than $5 \%)$

The following hypothesis was formed

- There is no correlation between the Penalty System and Tax Evasion at a 5\% level of significance.

- The hypothesis has been rejected and this indicates that there is a clear correlation between the Penalty System and Tax Evasion.

The following figure explains that

Test Type: One sample test

One-Sample Statistics

\begin{tabular}{|l|l|l|l|l|}
\hline & N & Mean & Std. Deviation & Std. Error Mean \\
\hline $\mathrm{f4}$ & 44 & 9.6818 & 2.56789 & .38712 \\
\hline
\end{tabular}

One-Sample Test

\begin{tabular}{|c|c|c|c|c|c|c|}
\hline & \multicolumn{6}{|c|}{ Test Value $=2.5$} \\
\hline & \multirow[t]{2}{*}{$\mathbf{T}$} & \multirow[t]{2}{*}{ df } & \multirow[t]{2}{*}{ Sig. (2-tailed) } & \multirow{2}{*}{$\begin{array}{l}\text { Mean } \\
\text { Difference }\end{array}$} & \multicolumn{2}{|c|}{$\begin{array}{l}\text { 95\% Confidence Interval of } \\
\text { the Difference }\end{array}$} \\
\hline & & & & & Lower & Upper \\
\hline f4 & 18.552 & 43 & .000 & 7.18182 & 6.4011 & 7.9625 \\
\hline
\end{tabular}

\section{Widened Questionnaire Test on SPSS System}

Analyses according to sex:

- Statistics related to sex were as the follow male: 33 but female 11.

- $\quad$ The percentage ratio of male was 75.0 but female was 25.0 
- $\quad$ The percentage of male was 75.0 and female was 25.0

- Cumulative Percent was 75.0 for male but 100.0 for female.

\section{Statistics}

\begin{tabular}{|l|l|}
\hline $\mathbf{N}$ & Valid \\
Missing & $\mathbf{4 4}$ \\
\hline
\end{tabular}

Gender

\begin{tabular}{|ll|l|l|l|l|}
\hline & & Frequency & Percent & Valid Percent & $\begin{array}{l}\text { Cumulative } \\
\text { Percent }\end{array}$ \\
\hline \multirow{4}{*}{ Valid } & male & 33 & 75.0 & 75.0 & 75.0 \\
& female & 11 & 25.0 & 25.0 & 100.0 \\
& Total & 44 & 100.0 & 100.0 & \\
\hline
\end{tabular}

Descriptive statistics: from deviation and Arithmetic mean

Descriptive statistics for male was 44 and for female 44, the Maximum was for male and female was 2.00 and the Minimum was -1.00

- The arithmetic mean was 1.2500

- The standard devastation was 4380

Descriptive Statistics

\begin{tabular}{|l|l|l|l|l|l|}
\hline & $\mathrm{N}$ & Minimum & Maximum & Mean & Std. Deviation \\
\hline Gender & 44 & 1.00 & 2.00 & 1.2500 & .43802 \\
Valid N (list wise) & 44 & & & & \\
\hline
\end{tabular}

Age analysis

First the ages were different from $20-40$

The frequency for ages $20-26$ is 22

The frequency for ages $31-36$ is 7

The frequency for ages $36-40$ is 3

\begin{tabular}{|c|c|c|}
\hline \multirow{2}{*}{$\mathbf{N}$} & Valid & 44 \\
\hline & Missing & 0 \\
\hline
\end{tabular}

Age
\begin{tabular}{|ll|l|l|l|l|}
\hline \multicolumn{2}{|c|}{} & Frequency & Percent & Valid Percent & Cumulative Percent \\
\hline \multirow{4}{*}{ Valid } & 26.00 & 22 & 50.0 & 50.0 & 50.0 \\
& $26-30$ & 12 & 27.3 & 27.3 & 77.3 \\
& $31-35$ & 7 & 15.9 & 15.9 & 93.2 \\
& $36-40$ & 3 & 6.8 & 6.8 & 100.0
\end{tabular}




Age
\begin{tabular}{|ll|l|l|l|l|}
\hline & Frequency & Percent & Valid Percent & Cumulative Percent \\
\hline \multirow{4}{*}{ Valid } & 26.00 & 22 & 50.0 & 50.0 & 50.0 \\
& $26-30$ & 12 & 27.3 & 27.3 & 77.3 \\
& $31-35$ & 7 & 15.9 & 15.9 & 93.2 \\
& $36-40$ & 3 & 6.8 & 6.8 & 100.0 \\
& Total & 44 & 100.0 & 100.0 & \\
\hline
\end{tabular}

Descriptive Statistics

\begin{tabular}{|l|l|l|l|l|l|}
\hline & N & Minimum & Maximum & Mean & Std. Deviation \\
\hline Age & 44 & 1.00 & 4.00 & 1.7955 & .95429 \\
Valid N (list wise) & 44 & & & & \\
\hline
\end{tabular}

The percentage was

20 to $26=50.0$

26 to $30=27.0$

31 to $35=15.9$

35 to $40=6.8$

Standard Deviation was 95429

Mean was 1.7955

Qualifications Statistics

Diploma frequency $=4$

Bachelor Degree $=33$

Master's Degree $=7$

Whereas Doctorate $=$ Zero

Percentage

Diploma $=9.0$

Bachelor Degree $=75.0$

Master Degree $=15.0$

Deviation $=5.0106$

Mean $=3.0682$

\begin{tabular}{|c|c|c|}
\hline & & \\
\hline & & \\
\hline $\mathbf{N}$ & Valid & 44 \\
\hline $\mathbf{N}$ & Missing & 0 \\
\hline
\end{tabular}




\begin{tabular}{|l|l|l|l|l|l|}
\hline \multicolumn{2}{|l|}{ Qualification } & Frequency & Percent & Valid Percent & $\begin{array}{l}\text { Cumulative } \\
\text { Percent }\end{array}$ \\
\hline \multirow{4}{*}{ Valid } & Diploma & 4 & 9.1 & 9.1 & 9.1 \\
\cline { 2 - 6 } & Bachelor & 33 & 75.0 & 75.0 & 84.1 \\
\cline { 2 - 6 } & Master & 7 & 15.9 & 15.9 & 100.0 \\
\cline { 2 - 6 } & Total & 44 & 100.0 & 100.0 & \\
\hline
\end{tabular}

\begin{tabular}{|c|c|c|c|c|c|}
\hline \multicolumn{6}{|l|}{ Descriptive Statistics } \\
\hline & $N$ & Minimum & Maximum & Mean & Std. Deviation \\
\hline Qualification & 44 & 1.00 & 3.00 & 2.0682 & .50106 \\
\hline Valid N (list wise) & 44 & & & & \\
\hline
\end{tabular}

Specialties Statistics

Finance Sciences' frequency $=5$

Economy $=2$

Whereas accounting $=37$

The percentage

Finance Sciences 11.4

Economy $=4.5$

Accounting $=84.0$

Standard Deviation $=6.59938$

Arithmetic mean $=3.72727$

\begin{tabular}{|c|c|c|}
\hline \multicolumn{3}{|c|}{ Statistics } \\
\hline \multicolumn{3}{|c|}{ Specialty } \\
\hline \multirow{2}{*}{$\mathbf{N}$} & Valid & 44 \\
\hline & Missing & $\mathbf{0}$ \\
\hline
\end{tabular}

Specialty

\begin{tabular}{|c|c|c|c|c|c|}
\hline & & Frequency & Percent & Valid Percent & $\begin{array}{l}\text { Cumulative } \\
\text { Percent }\end{array}$ \\
\hline \multirow{4}{*}{ Valid } & $\begin{array}{l}\text { Finance } \\
\text { Sciences }\end{array}$ & 5 & 11.4 & 11.4 & 11.4 \\
\hline & Economy & 2 & 4.5 & 4.5 & 15.9 \\
\hline & Accounting & 37 & 84.1 & 84.1 & 100.0 \\
\hline & Total & 44 & 100.0 & 100.0 & \\
\hline
\end{tabular}


Descriptive Statistics

\begin{tabular}{|l|l|l|l|l|l|}
\hline & N & Minimum & Maximum & Mean & Std. Deviation \\
\hline $\begin{array}{l}\text { specialty } \\
\text { Valid N (list wise) }\end{array}$ & 44 & 2.000 & 4.000 & 3.72727 & .659938 \\
\hline
\end{tabular}

Experiences Analysis

Without Experience frequency $=11$

Two years $=14$

Five years 13

Whereas more than five years $=6$

Percentage

Without experience $=25.0$

Two years $=31.8$

Five years $=29$

More than five years 13.0

Standard Deviation $=1.00632$

Arithmetic Mean $=2.318$

\section{Statistic}

Experiences

\begin{tabular}{|c|c|c|}
\hline $\mathbf{N}$ & $\begin{array}{l}\text { Valid } \\
\text { Missing }\end{array}$ & $\begin{array}{l}44 \\
0\end{array}$ \\
\hline
\end{tabular}

Experiences

\begin{tabular}{|ll|l|l|l|l|}
\hline & Frequency & Percent & Valid Percent & $\begin{array}{l}\text { Cumulative } \\
\text { Percent }\end{array}$ \\
\hline \multirow{4}{*}{ Without } & 11 & 25.0 & 25.0 & 25.0 \\
2 years & 14 & 31.8 & 31.8 & 56.8 \\
5 years & 13 & 29.5 & 29.5 & 86.4 \\
+ 5 years & 6 & 13.6 & 13.6 & 100.0 \\
Total & 44 & 100.0 & 100.0 & \\
\hline
\end{tabular}

Descriptive Statistics

\begin{tabular}{|l|l|l|l|l|l|}
\hline & $\mathrm{N}$ & Minimum & Maximum & Mean & Std. Deviation \\
\hline Experiences & 44 & 1.00 & 4.00 & 2.3182 & 1.00632 \\
Valid N (list wise) & 44 & & & & \\
\hline
\end{tabular}




\section{Statistic Questions}

Question1

\begin{tabular}{|l|l|l|l|l|}
\hline & Frequency & Percent & Valid Percent & $\begin{array}{l}\text { Cumulative } \\
\text { Percent }\end{array}$ \\
\hline Valid $\begin{array}{c}\text { Totally } \\
\text { agree }\end{array}$ & 44 & 100.0 & 100.0 & 100.0 \\
\hline
\end{tabular}

Question2

\begin{tabular}{|l|l|l|l|l|}
\hline & Frequency & Percent & Valid Percent & $\begin{array}{l}\text { Cumulative } \\
\text { Percent }\end{array}$ \\
\hline Totally agree & 23 & 52.3 & 52.3 & 52.3 \\
Valid agree & 19 & 43.2 & 43.2 & 95.5 \\
Neither & 2 & 4.5 & 4.5 & 100.0 \\
Total & 44 & 100.0 & 100.0 & \\
\hline
\end{tabular}

Question3

\begin{tabular}{|l|l|l|l|l|}
\hline & Frequency & Percent & Valid Percent & $\begin{array}{l}\text { Cumulative } \\
\text { Percent }\end{array}$ \\
\hline $\begin{array}{l}\text { I know them } \\
\text { I know much of } \\
\text { them } \\
\text { I know some of } \\
\text { them } \\
\text { I know nothing } \\
\text { of them } \\
\text { Total }\end{array}$ & 17 & 2.3 & 2.3 & 2.3 \\
\hline Valid & 17 & 38.6 & 38.6 & 40.9 \\
\hline
\end{tabular}

Question4

\begin{tabular}{|c|l|l|l|l|l|}
\hline & Frequency & Percent & Valid Percent & $\begin{array}{l}\text { Cumulative } \\
\text { Percent }\end{array}$ \\
\hline Answer A & 20 & 45.5 & 45.5 & 45.5 \\
Answer B & 9 & 20.5 & 20.5 & 65.9 \\
Valid & Answer C & 7 & 15.9 & 15.9 & 81.8 \\
& Answer D & 7 & 15.9 & 15.9 & 97.7 \\
Answer E & 1 & 2.3 & 2.3 & 100.0 \\
Total & 44 & 100.0 & 100.0 & \\
\hline
\end{tabular}


Question5

\begin{tabular}{|ll|l|l|l|l|}
\hline & & Frequency & Percent & Valid Percent & Cumulative Percent \\
\hline \multirow{4}{*}{ Valid } & Answer A & 15 & 34.1 & 34.1 & 34.1 \\
& Answer B & 6 & 13.6 & 13.6 & 47.7 \\
& Answer C & 5 & 11.4 & 11.4 & 59.1 \\
& Answer D & 18 & 40.9 & 40.9 & 100.0 \\
& Total & 44 & 100.0 & 100.0 & \\
\hline
\end{tabular}

Question6

\begin{tabular}{|ll|l|l|l|l|}
\hline & Frequency & Percent & Valid Percent & Cumulative Percent \\
\hline \multirow{4}{*}{$\begin{array}{l}\text { Totally } \\
\text { agree }\end{array}$} & 24 & 54.5 & 54.5 & 54.5 \\
Valid & Agree & 18 & 40.9 & 40.9 & 95.5 \\
& Neither & 2 & 4.5 & 4.5 & 100.0 \\
& Total & 44 & 100.0 & 100.0 & \\
\hline
\end{tabular}

Question8

\begin{tabular}{|c|c|c|c|c|c|}
\hline & & Frequency & Percent & Valid Percent & \begin{tabular}{|l} 
Cumulative \\
Percent
\end{tabular} \\
\hline \multirow{5}{*}{ Valid } & $\begin{array}{l}\text { Totally } \\
\text { agree }\end{array}$ & 23 & 52.3 & 52.3 & \\
\hline & Agree & 17 & 38.6 & 38.6 & 90.9 \\
\hline & disagree & 1 & 2.3 & 2.3 & 93.2 \\
\hline & Neither & 3 & 6.8 & 6.8 & 100.0 \\
\hline & Total & 44 & 100.0 & 100.0 & \\
\hline
\end{tabular}

Question9

\begin{tabular}{|c|c|c|c|c|c|}
\hline & & Frequency & Percent & Valid Percent & $\begin{array}{l}\text { Cumulative } \\
\text { Percent }\end{array}$ \\
\hline \multirow{5}{*}{ Valid } & $\begin{array}{l}\text { Totally } \\
\text { agree }\end{array}$ & 11 & 25.0 & 25.0 & 25.0 \\
\hline & Agree & 27 & 61.4 & 61.4 & 86.4 \\
\hline & disagree & 2 & 4.5 & 4.5 & 90.9 \\
\hline & Neither & 4 & 9.1 & 9.1 & 100.0 \\
\hline & Total & 44 & 100.0 & 100.0 & \\
\hline
\end{tabular}


Question10

\begin{tabular}{|c|c|c|c|c|c|}
\hline & & Frequency & Percent & Valid Percent & $\begin{array}{l}\text { Cumulative } \\
\text { Percent }\end{array}$ \\
\hline \multirow{5}{*}{ Valid } & $\begin{array}{l}\text { Totally } \\
\text { agree }\end{array}$ & 5 & 11.4 & 11.4 & 11.4 \\
\hline & Agree & 34 & 77.3 & 77.3 & 88.6 \\
\hline & Disagree & 2 & 4.5 & 4.5 & 93.2 \\
\hline & Neither & 3 & 6.8 & 6.8 & 100.0 \\
\hline & Total & 44 & 100.0 & 100.0 & \\
\hline
\end{tabular}

Question11

\begin{tabular}{|c|c|c|c|c|c|}
\hline & & Frequency & Percent & Valid Percent & \begin{tabular}{|l|} 
Cumulative \\
Percent
\end{tabular} \\
\hline \multirow{5}{*}{ Valid } & $\begin{array}{l}\text { Totally } \\
\text { agree }\end{array}$ & 9 & 20.5 & 20.5 & 20.5 \\
\hline & Agree & 33 & 75.0 & 75.0 & 95.5 \\
\hline & Disagree & 1 & 2.3 & 2.3 & 97.7 \\
\hline & Neither & 1 & 2.3 & 2.3 & 100.0 \\
\hline & Total & 44 & 100.0 & 100.0 & \\
\hline
\end{tabular}

Question12

\begin{tabular}{|c|l|l|l|l|l|}
\hline & Frequency & Percent & Valid Percent & $\begin{array}{l}\text { Cumulative } \\
\text { Percent }\end{array}$ \\
\hline \multirow{4}{*}{$\begin{array}{l}\text { Totally } \\
\text { agree }\end{array}$} & 13 & 29.5 & 29.5 & 29.5 \\
Valid & Agree & 24 & 54.5 & 54.5 & 84.1 \\
disagree & 3 & 6.8 & 6.8 & 90.9 \\
Neither & 4 & 9.1 & 9.1 & 100.0 \\
Total & 44 & 100.0 & 100.0 & \\
\hline
\end{tabular}

Question13

\begin{tabular}{|c|c|c|c|c|c|}
\hline & & Frequency & Percent & Valid Percent & $\begin{array}{l}\text { Cumulative } \\
\text { Percent }\end{array}$ \\
\hline \multirow{3}{*}{ Valid } & $\begin{array}{l}\text { Totally } \\
\text { agree }\end{array}$ & 15 & & & \\
\hline & Agree & 29 & 65.9 & 65.9 & 100.0 \\
\hline & Total & 44 & 100.0 & 100.0 & \\
\hline
\end{tabular}


Question14

\begin{tabular}{|c|c|c|c|c|c|}
\hline & & Frequency & Percent & Valid Percent & \begin{tabular}{|l|} 
Cumulative \\
Percent
\end{tabular} \\
\hline \multirow{5}{*}{ Valid } & $\begin{array}{l}\text { Totally } \\
\text { agree }\end{array}$ & 10 & 22.7 & 22.7 & 22.7 \\
\hline & Agree & 31 & 70.5 & 70.5 & 93.2 \\
\hline & Disagree & 1 & 2.3 & 2.3 & 95.5 \\
\hline & Neither & 2 & 4.5 & 4.5 & 100.0 \\
\hline & Total & 44 & 100.0 & 100.0 & \\
\hline
\end{tabular}

\section{Conclusion}

- Accounting system plays a main role at tax department whereas ineffective accounting system leads to tax evasion.

- Experience is associated with tax evasion; Taxpayer's opportunities in tax evasion are increased by high experience.

- Tax price affects tax evasion.

- Tax evasion is associated with accounting system through penal \& control system, in case of un-existing of controlling system, laws and strict penalties lead to tax evasion and neglecting at tax department.

\section{Recommendations}

1- Not to deal with both accounting information system and management information system partially and focus on one of them without the other which means establishing developed and computerized management and accounting information system to reduce tax evasion.

2- To consider about related characteristics of the suggested system to the quality of appropriate information represented in ensuring and trusting the information or the neutral and depending on the information to be compared and for appropriate timing in addition to the ability of information and perfect disclosure.

3- Suggested system must observe using active and efficient contribution of system in tax, accounting and management control to reduce tax evasion e.g. cases and objections and what is related.

4- Suggested system must observe un-financial information which reducing tax evasion and what is related.

5- Must work on awarding citizens with his tax duties and remove psychological barrier between taxpayer and tax department.

6- Build bridges of relationships based on trust, relief and respect between taxpayer and tax department. 
7- Concentrate on tax return since all taxpayers be abided to introduce this tax return for its importance in facilitating tax departments works.

\section{References:}

Khalil Al-Rifai, Information System used in Sales \& Income Tax Department and its effect on income tax efficiency, Amman 2013 Khalil Awad Abu Hashish, Advanced Studies in Accounting, 2004. Ahmad Ali - Tax Reference Book - Accountant and Auditor - published in 2005.

Farghaly Hassan Ahmad- Harmonized Accounting System - Cairo 2003.

Al Khateeb, research about tax evasion. Damascus University, second issue 2000.

Al Alqawy, evaluating effective factors in income tax assessors to reduce tax evasion2006.

Alshahrany- Abdullah Shabnan Sa'eed Alshahrany's Master Thesis discussed the reasons of tax evasion- Financia Sciences College- King Saud University 2004

Hadad, the role of controlling procedures and accounting rules to reduce tax evasion 2006.

Husam Abu Ali Hijawy, assets Practical and scientific in tax accounting and tax applications 2004

Mansour Nafez, effective tax penalties in reducing tax evasion, master thesis, Palestine 2003 